\title{
Seedling characteristics in the Casuarinaceae
}

\author{
Robin Hwang and John G. Conran
}

\begin{abstract}
Hwang, Robin ${ }^{1}$ and Conran, John G.2,3 (1Research Division, National Museum of Natural Science, Taichung, Taiwan; ${ }^{2}$ Department of Environmental Biology, The University of Adelaide, SA, Australia 5005; ${ }^{3}$ author for correspondence) 2000. Seedling characteristics in the Casuarinaceae. Telopea 8(4): 429-439. Seedling characters and their distributions within the genera of the Casuarinaceae and their sections are described for 45 taxa in the family representing three of the four genera and all 14 of the currently recognised sections in Allocasuarina. The cotyledons in Gymnostoma are petiolate, a feature absent from the other taxa examined. There were no obvious genus-level seedling features distinguishing either Casuarina or Allocasuarina, although red-purple cotyledons at senescence are common in Casuarina but rare in Allocasuarina. Several features are informative at the sectional level: suppression of secondary cotyledon branches is only found in Allocasuarina sects, Oxypitys, Platypitys, Echinopitys and Ceropitys, as were abortion of the primary shoot and divergent tooth apices, the latter two characters otherwise found only in A. monilifera and A. microstachya. Seedlings of sect. Ceropitys showed a distinctive growth habit making them look like Lycopodium shoots with outgrowths resembling microphylls.
\end{abstract}

\section{Introduction}

The Casuarinaceae are an unusual family of dicotyledons from SE Asia, Australia and Oceania. Within the Casuarinaceae there are four genera and about 80 species of which three genera and 66 species occur in Australia, most of which are endemic (Johnson \& Wilson 1993). Bentham (1873) classified the species largely on cone bracteoles (valves), whereas Diels and Pritzel (1905) emphasised features of the vegetative branchlets. Modern relationships in the family are based largely on Poisson's (1874) division of Casuarina sens. lat. into the Gymnostomae (= Gymnostoma) and Cryptostomae (the remainder) using stomatal features. Barlow (1959) divided the Cryptostomae into 'Group A' and 'Group B' based on cytology, and Johnson (1982) expanded Barlow's ideas, establishing Allocasuarina for Group B with Group A representing Casuarina s. str. The Gymnostomae were raised to generic rank as Gymnostoma (Johnson 1980) with c. 18 species from SE Asian wet tropical forests, and Ceuthostoma for two Malesian Gymnostoma-like species which lack a broad bract under the bracteole pair and which possess antrorse anthers and very long-bracteolate cones on long branchlets (Johnson 1988).

There are three genera in Australia (Wilson \& Johnson 1989): Gymnostoma has a single extant native species, although fossil evidence suggests that the genus was much more diverse during the Eocene (Christophel 1980, Scriven \& Christophel 1990) and Palaeocene (Scriven \& Hill 1995). Casuarina has six widespread native species, generally on fertile soils, whereas the endemic Allocasuarina with 14 sections and 60 species is frequently associated with nutrient-deficient soils (Wilson \& Johnson 1989). Although many Allocasuarina sections are mono- or oligotypic, most species belong to sect. Cylindropitys (29 spp.) or sect. Ceropitys (nine spp.). Cylindropitys, in particular, consists of many closely related taxa thought to represent a recent evolutionary radiation (Wilson \& Johnson 1989). 
Cytology and karyotype (Barlow 1959, 1983) support several of the fruit, bracteole and samara-based subdivisions in the family (Johnson \& Wilson 1989). There are also studies detailing pollen (Kershaw 1970), anatomy (Williams \& Metcalf 1985), stem morphology (Torrey \& Berg 1988), 17 stem, tooth and stomate characters in Gymnostoma and the other genera in the family, especially as fossils (Scriven \& Christophel 1990, Scriven \& Hill 1995), and 22 vegetative, stomatal and reproductive characters for extant genera (Dilcher et al. 1990).

De Candolle (1846) stressed the taxonomic value of seedling morphology. Seedling characters were deemed useful in angiosperm classification (de Vogel 1980), especially if adult material was difficult to obtain or the plants had long life cycles. Clifford (1991) and $\mathrm{Li}$ and Hsieh (1997) observed that members of the same genus often have similar seedling characteristics. Léonard (1957) advocated that there should be only one type of seedling in a 'good' genus, and that genera should differ significantly in their seedling morphology. Nevertheless, Weberling and Leenhouts (1966) proposed that genera should not necessarily be divided on seedling variation. Conran et al. (1997) found that for some taxa, seedling characters were more useful at subgeneric and sectional levels, rather than generic.

Boodle and Worsdell (1894), commenting on the higher level relationships of Casuarina, included seedling information, and Duke (1965), Burger (1972), Torrey (1983) and Boland et al. (1984) described or illustrated seedling morphology for a number of Casuarinaceae species. Their listed characteristics included root colour; lateral root abundance; hypocotyl position against the soil; hypocotyl colour and length; cotyledon shape, index, attachment, apex and base shape, adaxial and abaxial colour, texture and indumentum; epicotyl length (first internode above the hypocotyl), stem straightness; number of leaves (teeth) per whorl and tooth shape, colour and length. Unfortunately data were provided for few taxa, and generally without systematic sampling within the family.

This present study investigates seedling morphology in the Casuarinaceae, comparing the results against the current classification of Wilson and Johnson (1989) and the adult morphology-based studies of Dilcher et al. (1990) and Scriven and Hill (1995) to examine the distribution and usefulness of seedling features in the family.

\section{Materials and methods}

Seeds from 123 provenances representing eight Casuarina and 34 Allocasuarina taxa were obtained from various sources detailed previously in Hwang and Conran (1991). The seeds were soaked overnight under running tap water, and germinated on wet cotton wool in an unheated glass house (temperature range $10-35^{\circ} \mathrm{C}$ ) under natural lighting. Casuarinaceae seeds germinate readily, mostly in $15-30$ days at $20-25^{\circ} \mathrm{C}$ (Elliot \& Jones 1982), and most species benefit from daily exposure to light during germination (Turnbull \& Martensz 1982). Pre-soaking the seeds in water for 24 hours improves germination rates (Kuo 1984). A summary of the germination features for Australian Casuarina and Allocasuarina species is given in Hwang and Conran (1991).

Germinated seeds were planted $40 \mathrm{~mm}$ apart and $10 \mathrm{~mm}$ deep in drained plastic trays with an unfertilised, unsterilised 2:2:1:1 soil mixture of coarse river sand, fine pine bark, red mountain soil and grey sandy loam. There were 15 columns $\times 7$ rows per tray, with 21 seedlings per provenance. Average seedling survival per provenance was 18.8 (range 1 to 21), and the seedlings were grown and observed for 3 months with daily watering. With the exception of ephemeral or developmental characters, data were recorded from three month old seedlings and scored as the average of all surviving seedlings for each taxon. Data for Casuarina junghuhniana Miq. were taken from the 
published description of its seedlings by Burger (1972). Seedling data for Gymnostoma australianum L. Johnson were obtained from plants grown from seeds collected at Noah Creek (Qld) by Dr D.C. Christophel and used in a study by Prider (1998).

The seedling characters and their states were recorded as follows:

(1) Primary roots red (1) or white to yellowish (0).

(2) Cotyledon orientation in relation to the stem apex (Fig. 1a): level (0), ascending (1) or descending (2).

(3) Cotyledon apex shape (Fig. 1b): rounded (0), obtuse (1), acute (2).

(4) Base of the cotyledons (Fig. 1c): not markedly constricted (0), constricted (1), petiolate (2).

(5) Cotyledon shape in cross-section (Fig. 1d): flat (0), slightly convex (1), convex (2).

(6) Colour of senescing cotyledons: yellow to light brown (0) red purple to dark rustred (1).

(7) Cotyledons pubescent: absent (0), present (1).

(8) Number of axillary branchlets developing in the cotyledons.

(9) Cotyledonary axillary branchlets: only developing after those of the primary stem

(1); developing at the same time as the primary stem (0).

(10) Epicotyl-base colour: green to yellow (0) or red to purple (1).

(11) Primary shoot orientation (Fig. 1e): erect (0), slightly curved (1), strongly curved

(2) or recurved/curled (3).

(12) Primary branching (Fig. 1f): simple (0) or compound (1).

(13) Node number on the main shoot at which branching first occurs (Fig. 1g) excluding the cotyledonary node.

(14) Axillary branch supression zone (Fig. 1h): absent (0); present (1).

(15) Primary stem: developing normally (0); suppressed and replaced by cotyledonary or basal lateral shoots (1).

(16) Lateral branchlets (Fig. 1i): strongly curved (1); or straight (0).

(17) Number of teeth primary shoot node 15.

(18) Tooth bases on lateral branchlets (Fig. 1j): imbricate (1); valvate (0).

(19) Lateral branch tooth apices (Fig. 1k): closely appressed (0); or with loosely attached, spreading, or divergent apices (1).

(20) Seedling growth form: stems jointed but without obvious microphyll-like protrusions (0); strongly resembling Lycopodium shoots and having the appearance of bearing microphylls (1).

\section{Results}

The results characters are summarised in Table 1.

The primary root (character 1) was red in Gymnostoma and the majority of Casuarina and Allocasuarina sects Allocasuarina, Cylindropitys, Nannopitys, and Trichopitys, while Allocasuarina sects Dolichopitys, Echinopitys and Oxypitys had yellow- or white-rooted seedlings although both colour types were represented in most sections.

The cotyledon orientation (2) was horizontal in the majority of the taxa examined, except for A. acutivalvis and A. paradoxa where it was descending, and A. thuyoides where it was ascending. The cotyledon apex (3) was usually rounded, although it was obtuse in four species of Allocasuarina, mostly in sect. Cylindropitys, and acute in four other species of Allocasuarina. Cotyledon bases (4) were distinctly petiolate only in Gymnostoma, not only for G. australianum, but also in seedlings of G. vitiense which were grown for this study but which did not survive beyond the cotyledon stage. The base of the cotyledons was markedly constricted in all Casuarina spp., but four species of Allocasuarina in different sections. Cotyledon shape in cross-section (5), although 

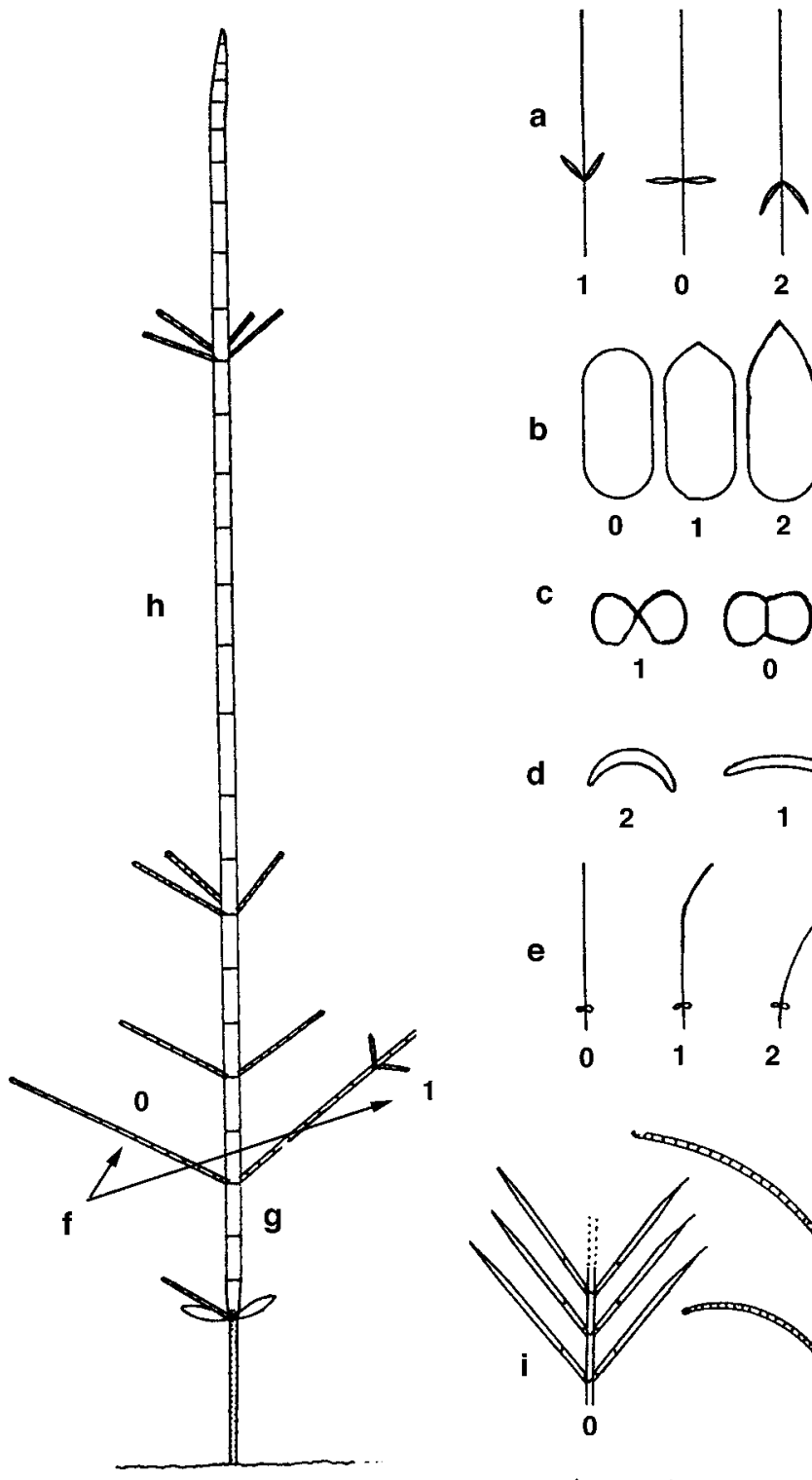

b

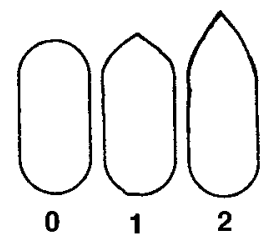

C

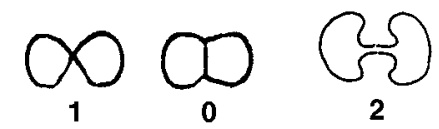

d
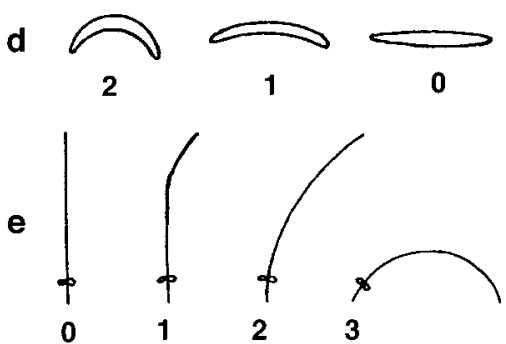

$\mathbf{k}$
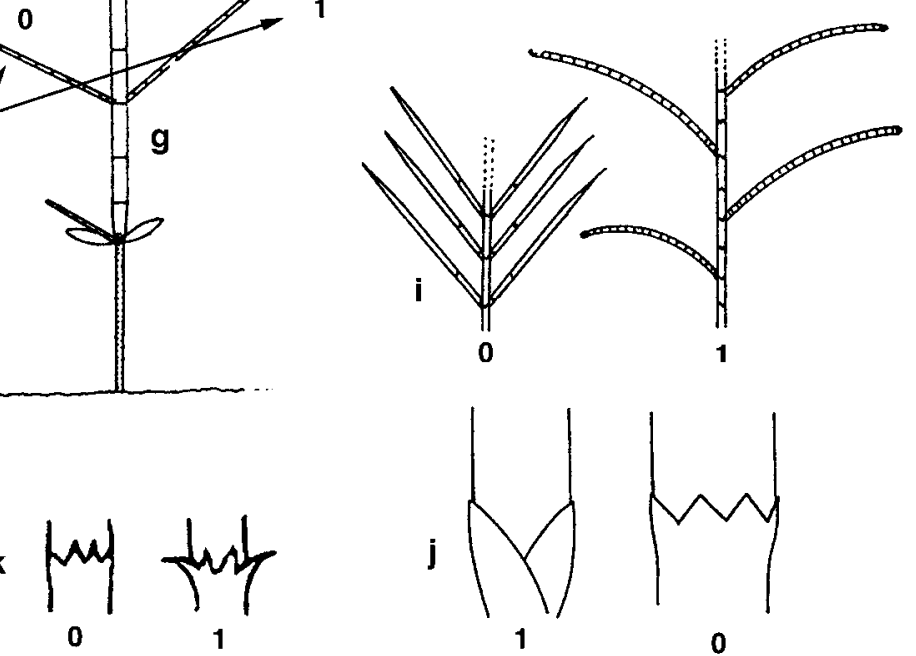

Fig. 1. Seedling characteristics of the Casuarinaceae, details outlined in the materials and methods. $\mathbf{a}$, cotyledon orientation; $\mathbf{b}$, cotyledon apex shape; $\mathbf{c}$, cotyledon basal constriction; $\mathbf{d}$, cotyledon cross-sectional shape; e, shoot orientation (bending); $\mathbf{f}$, primary branches simple or compound; $\mathbf{g}$, node number at first branching; $\mathbf{h}$, axillary branch sterile zone; $\mathbf{i}$, lateral branch curvature; $\mathbf{j}$, lateral branch tooth bases; $\mathbf{k}$, lateral branch tooth apical spread. Character code numbers are those listed in the text. 


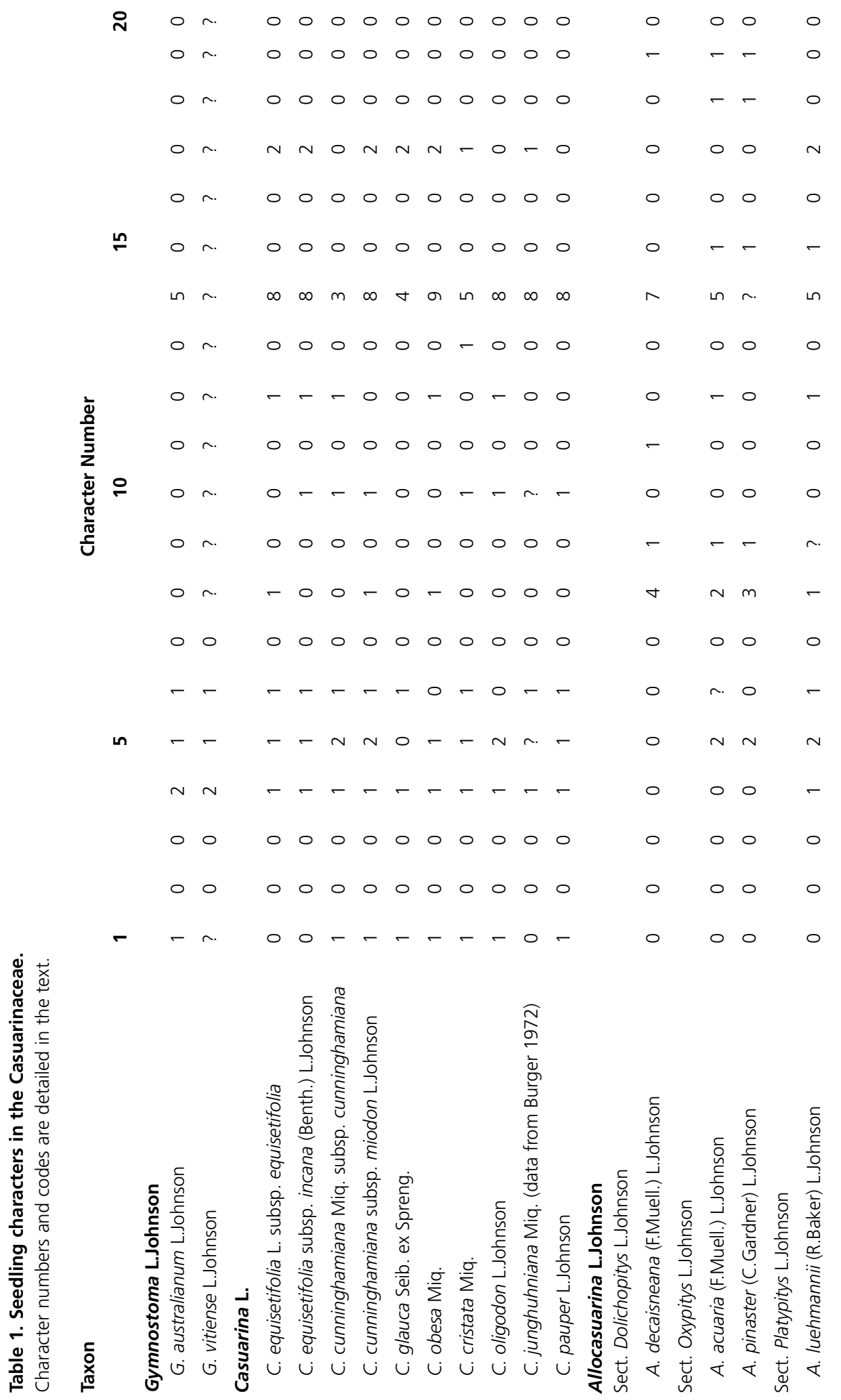




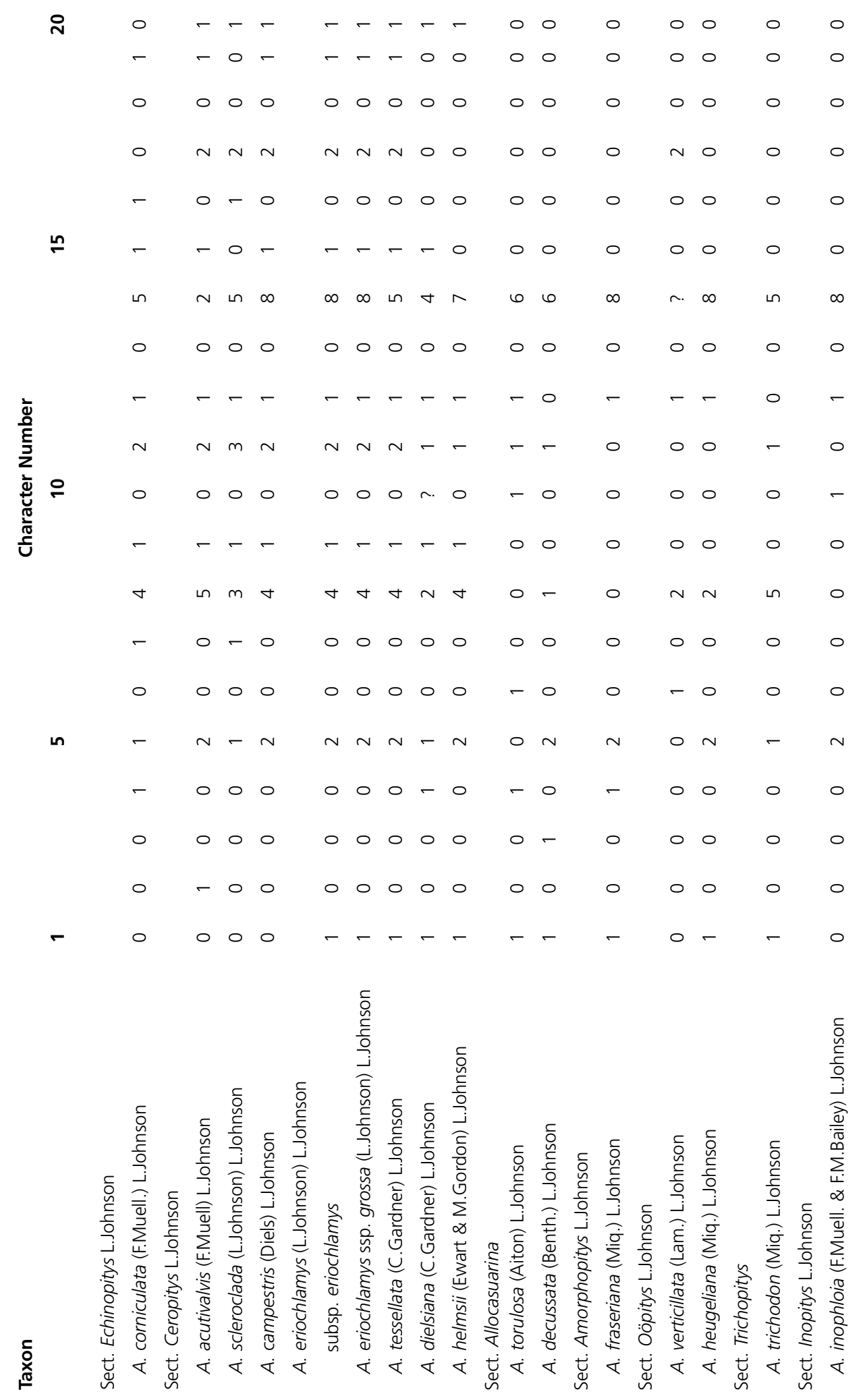



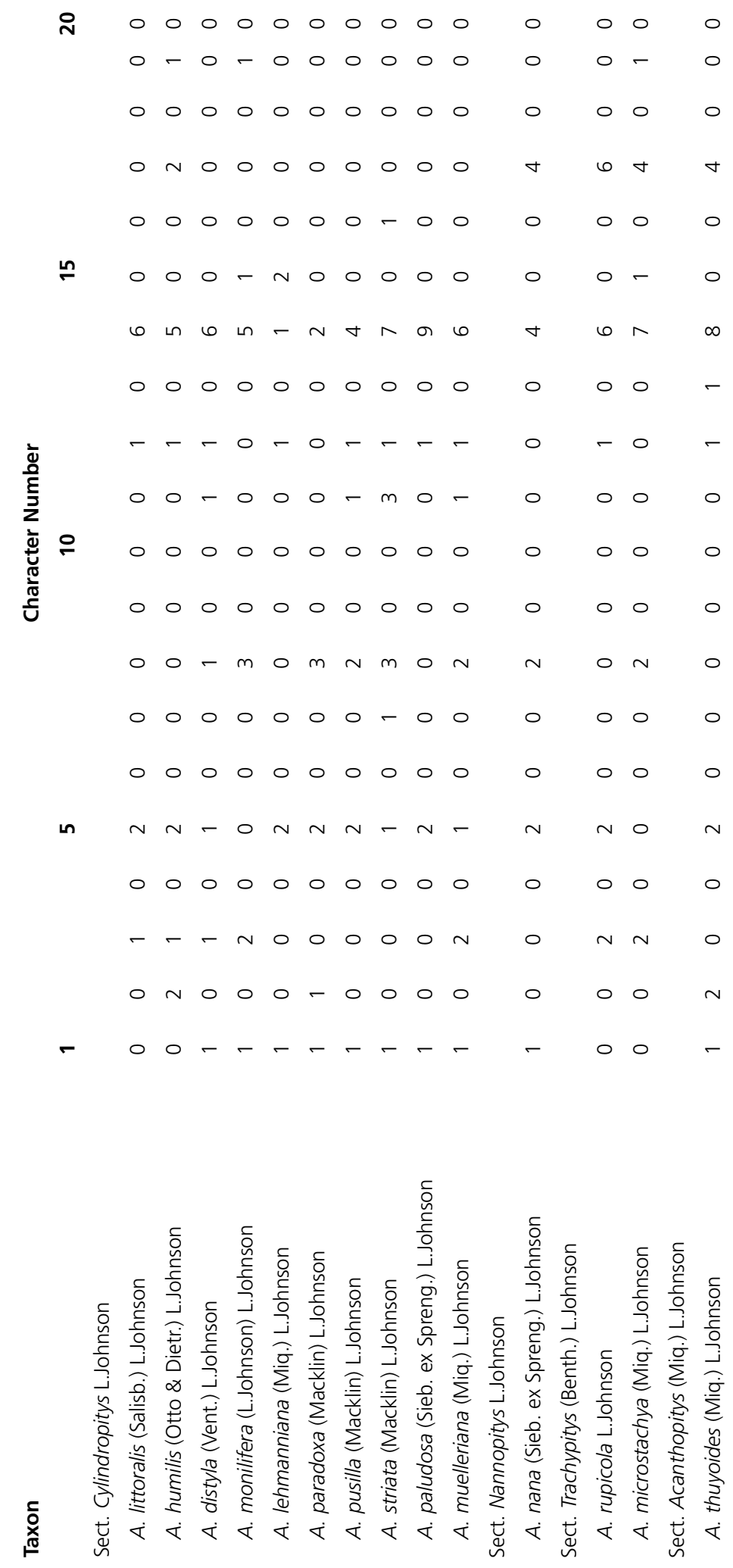
constant within species, was highly variable within the genera and sections, with no clear patterns apparent.

The colour of the cotyledons at senescence (6) differed from the pattern seen for roots of the same species, and was divided into two states: yellow to light brown versus redpurple to dark rust-red, the latter was the most common condition in Gymnostoma and Casuarina, and yellow or light brown in Allocasuarina. Cotyledon pubescence (7) was uncommon, but was observed in three Allocasuarina species in different sections.

In $A$. acutivalvis, $A$. campestris, $A$. decaisneana and $A$. tessellata, the interpetiolar branchlets (9) always developed before those of the cotyledons, and these were then followed by lateral branchlets on the main shoot. In contrast, only interpetiolar branchlets were seen in C. cunninghamiana, C. cristata, C. obesa and C. glauca and then only developing later than and posterior to the lateral branchlets. In 12 species, apical dominance of the primary shoot was suppressed, with replacement by axillary branchlets (15).

Epicotyl-base colour (10) varied from green or yellow through to red or purple. As with cotyledon senescence, red or purple was most common in Casuarina. A. torulosa was the only Allocasuarina with a red-purple epicotyl and cotyledons.

Primary shoot shape (11) varied from erect (Gymnostoma, Casuarina and some Allocasuarina spp.), slightly curved (various Allocasuarina spp.), to strongly curved (the predominant condition in sections Echinopitys, Ceropitys) or even curled (A. scleroclada and $A$. striata). The lateral branches were also strongly curved in three species of Allocasuarina including some, but not all, species where the primary shoot curled or was strongly curved. The primary branches (12) were generally compound, but simple branches occur in a number of species, although there were no clear supra-specific patterns. Nevertheless, simple cotyledon branches were only found in Allocasuarina sects Dolichopitys, Oxypitys, Platypitys, Echinopitys and Ceropitys. The node number on the main shoot at which branching first occurred (13) was also largely constant within, but variable between, species ranging from the second node in $A$. paradoxa to the twelfth node in A. lehmanniana (both sect. Cylindropitys). There was an axillary branch sterile zone (14) present in C. cristata and A. thuyoides. In sections Oxypitys, Platypitys, Echinopitys, almost all of sect. Ceropitys, and A. monilifera and A. microstachya, a) the primary shoot aborts (15), and the main adult stem or stems develop from axillary shoots arising from the cotyledon axils, and b) the lateral branch stem tooth apices were divergent.

Node 15 on the primary stem (17) in Gymnostoma was 4-toothed, with the remainder of the species examined being 4- and 6-toothed (rarely 5-toothed). On lateral branchlets the tooth bases (18) were imbricate in Allocasuarina sect. Oxypitys. Seedlings of Allocasuarina sect. Ceropitys, up to about three months old, superficially resemble shoots of the fern ally Lycopodium, where there are protrusions along the stems which give the impression of micophylls - a feature also noted by Torrey (1983).

\section{Discussion}

Seedling structure within the family is distinctive and highly derived, reflecting the unusual adult morphology. Accordingly, meaningful comparisons with the seedlings of related families are difficult. The seedling data revealed a number of patterns in the different features. Gymnostoma seedlings, in particular, are readily identified by the single character of strongly petiolate cotyledons. Casuarina seedlings are not clearly distinguished from those of Allocasuarina, although they tend to have constricted cotyledon bases, and the senescent cotyledons and epicotyl are generally red to 
purple. Dilcher et al. (1990) and Scriven and Hill (1995) similarly found that both extant and fossil Casuarinaceae can be identified and assigned to genera on the basis of vegetative and reproductive anatomy. Red roots in the Casuarinaceae and some other families indicate high levels of leghaemoglobin (Martin \& Dowd 1993), where it is linked to nitrogen fixation by the soil actinomycete Frankia (Maggia \& Bousquet 1994). Although this is common throughout the family, it is mixed enough in its occurrence within each of the genera and sections to suggest that the feature has limited phylogenetic utility within the family.

In the Casuarinaceae, there are also several taxa where the seedling characteristics differ from those of the adults. For example, lateral branch tooth apices are divergent in juveniles of sect. Oxypitys, but appressed in the adults, and appressed in seedling A. dielsiana, A. heugeliana and A. pusilla (amongst others), but divergent in the adults. Similarly, whereas no Casuarina species have divergent teeth in the seedlings, adult C. obesa and C. glauca both possess them. In A. acutivalvis the branchlets changed gradually into the adult form, whereas in A. campestris and A. tessellata one or a few axillary shoots develop directly with adult morphology. Torrey (1983) also observed that adult branchlets develop after about $10 \mathrm{~cm}$ of juvenile growth, but in A. acutivalvis there can be reversal, where adult shoots revert to the juvenile form.

A phenetic analysis of the Casuarinaceae by Hwang (1989) using the characters described here, plus a series of growth rate-related characters found that there were several distinctive species assemblages, representing in decreasing order of dissimilarity: Allocasuarina sect. Oxypitys; a mixed group from Allocasuarina sects Ceropitys and Echinopitys; Casuarina sens. str. plus Allocasuarina torulosa (Aiton) L.Johnson; and then three groups consisting of mixtures of taxa from the remaining Allocasuarina sections sampled (see taxa listed in Hwang \& Conran 1991).

Prider's (1998) viability and embryological studies of Gymnostoma australianum demonstrated that the majority of the samaras produced were embryologically nonviable rather than short-lived, and that some of the few fertile seeds produced were still viable after 2 years. Similarly, Torrey (1983) was uncertain whether germination failure in several of the species that he examined was due to seed age or general low viability.

Relationships between series and sections in large genera can often be defined, at least in part, on seedling structure. Conran et al. (1997) found distinctive seedling-based groups in the Droseraceae which are taxonomically informative at the subgeneric and sectional levels, and which indicated that there are previously unpredicted relationships between them. Within Acacia (Mimosaceae), seedlings are distinctive at the subgeneric level (e.g. Burger 1972) and reflect features which, though present in the seedlings, are absent in mature plants. In Eucalyptus (Myrtaceae) the seedlings are also different between subgenera and between some of the sections (Chippendale 1988), with Maiden (1929-31) dividing the genus into three sections on cotyledon shape. Similarly, the E. flocktoniae and E. transcontinentalis complexes of series Subulatae both possess uniquely decussate-leaved seedlings (Nicolle \& Conran 1999). Weberling and Leenhouts (1966), Burger (1972) and Li and Hsieh (1997) also noted many examples of variable and potentially taxonomically useful seedling characters at the intrafamilial and infrageneric levels in a range of rainforest taxa.

The patterns seen here for some of the seedling characteristics in the Casuarinaceae suggest that there are some distinctive seedling-based species groupings. Allocasuarina sect. Ceropitys have lycopod-like seedlings, and simple cotyledon branches. Allocasuarina sects Dolichopitys, Oxypitys, Platypitys, Echinopitys and Ceropitys, had abortion of the primary shoot and divergent tooth apices characters otherwise found only in A. monilifera (sect. Cylindropitys) and A. microstachya (sect. Trachypitys). 
Although the treatment of the Casuarinaceae by Wilson and Johnson (1989) placed taxa close to their presumed relatives, there is no current phylogenetic classification of the family from which species relationships can be investigated. Our study provides good evidence that there are useful seedling characteristics in the Casuarinaceae which might be used to investigate generic, sectional and species relationships within the family. However, it is not the intention of this paper to reject one set of characters used to classify the family in favour of another. Rather, it is hoped that the seedling characters presented here can be incorporated with as wide as possible a range of features from adult, seed and pollen morphology plus cytology so that future phylogenetic studies of the family can assess objectively the relative contribution and merits of all the available information.

\section{Acknowledgments}

This work was undertaken as part of a Ph.D. by RH, and the Department of Ecology and Evolutionary Biology at Monash University is thanked for the provision of facilities, as is the Department of Environmental Biology at the University of Adelaide for supporting $\mathrm{RH}$ as a distinguished visiting fellow. The late Dr L.A.S. Johnson is thanked for stimulating comments on this research.

\section{References}

Barlow, B. (1959) Chromosome numbers in the Casuarinaceae. Austral. J. Bot. 7: 230-237.

Barlow, B.A. (1983) Casuarinas - a taxonomic and biogeographic review. Pp. 10-18, in Midgley, S.J., Turnbull, J.W. \& Johnston, R.D. (eds), Casuarina Ecology, Management and Utilization. (CSIRO: Melbourne).

Bentham, G. (1873) Flora Australiensis, vol. 6. (Reeve: London).

Boland, D.J., Brooker, M.I.H., Chippendale, G.M., Hall, N., Hyland, B.P.M., Johnston, R.D., Kleinig, D.A. \& Turner, J.D. (1984) Forest Trees of Australia. (CSIRO: Melbourne).

Boodle, L.A. \& Worsdell, W.C. (1894) On the comparative anatomy of the Casuarinaceae, with special reference to the Gnetaceae and Cupuliferae. Ann. Bot.(London) 8: 231-264.

Burger, H.D. (1972) Seedlings of some tropical trees and shrubs, mainly of South East Asia. (Centre for Agricultural Publishing and Documentation: Wageningen).

Chippendale, G.M. (1988) Eucalyptus. Pp. 1-447, in George, A.S. (ed.) Flora of Australia, vol. 19, Myrtaceae - Eucalyptus, Angophora. (AGPS: Canberra).

Christophel, D.C. (1980) Occurrence of Casuarina megafossils in the Tertiary of south-eastern Australia. Austral. J. Bot. 28: 249-259.

Clifford, H.T. (1991) Germination patterns in Dicotyledons. Aliso 13: 207-213.

Conran, J.G., Jauzdems, G. \& Hallam, N.D. (1997) Droseraceae germination patterns and their taxonomic significance. Bot. J. Linn. Soc. 123: 211-233.

de Candolle, A.L.P.P. (1846) Sur la durée relative de la faculté de germer dans des graines appartenant à diverses familles. Ann. Sci. Nat. Bot. sér. 3, 6: 373-382.

de Vogel, E.F. (1980) Morphological types in dicot seedlings with reference to their origin. Bull. Soc. Bot. France, Actual. Bot. 126: 173-182.

Diels, L. \& Pritzel, E. (1905) Fragmenta phytographiae australiae occidentalis. Bot. Jahrb. Syst. 35: 122-130.

Dilcher, D.L., Christophel, D.C., Bhagwandin, H.O., Jr. \& Scriven, L.J. (1990) Evolution of the Casuarinaceae: morphological comparisons of some extant species. Amer. J. Bot. 77: 338-355.

Duke, J.A. (1965) Keys for the identification of seedlings of some prominent woody species in forest types of Puerto Rico. Ann. Missouri Bot. Gard. 52: 315-350.

Elliot, W.R. \& Jones, D.L. (1982) Encyclopaedia of Australian Plants suitable for Cultivation, vol. 2. (Lothian: Melbourne).

Hwang, Y.H. (1989) Taxonomy of Australian Casuarinaceae based on seedling morphology and allozymes. Unpublished Ph.D. thesis, Monash University. 
Hwang, Y.H. \& Conran, J.G. (1991) Seedlings of Australian Casuarinas. I: Germination. W. Austral. Naturalist 18: 188-197.

Johnson, L.A.S. (1980) Notes on Casuarinaceae. Telopea 2: 83-84.

Johnson, L.A.S. (1982) Notes on Casuarinaceae II. J. Adelaide Bot. Gard. 6: 73-87.

Johnson, L.A.S. (1988) Notes on Casuarinaceae III: The new genus Ceuthostoma. Telopea 3: 133-137.

Johnson, L.A.S. \& Wilson, K.L. (1989) Casuarinaceae: a synopsis. Pp. 167-188, in Crane, P.R. \& Blackmore, S. (eds), Evolution, Systematics and Fossil History of the Hamamelideae, vol. 2. (Systematics Association/ Clarendon Press: Oxford).

Johnson, L.A.S. \& Wilson, K.L. (1993) Casuarinaceae. Pp. 237-242, in Kubitzki, K., Rohwer, J.G. \& Bittrich, V. (eds), The Families and Genera of Vascular Plants, vol. 2. Flowering Plants Dicotyledons. Magnoliid, Hamamelid and Caryophyllid Families. (Springer-Verlag: Berlin).

Kershaw, A.P. (1970) Pollen morphological variation within the Casuarinaceae. Pollen et Spores 12: 145-161.

Kuo, S.R. (1984) Studies on the seed germination and seedling growth of Casuarina [in Chinese]. Technical Bulletin of Experimental Forestry of the Taiwan University 154: 1-12.

Léonard, J. (1957) Genera des Cynometreae et des Amhersteae africaines (LeguminosaeCaesalpinioideae). Esai de blastogénie appliquée à la systématique. Mém. Acad. Roy. Sci. Belgique, Cl. Sci. 30: 1-312.

Li, S.-P. \& Hsieh, C.-F. (1997) Seedling morphology of some woody species in a subtropical rain forest on southern Taiwan. Taiwania 42: 207-238.

Maggia, L. \& Bousquet, J. (1994) Molecular phylogeny of the actinorhizal Hamamelidae and relationships with host promiscuity towards Frankia. Molec. Ecol. 3: 459-467.

Maiden, J.H. (1929-31) A Critical Revision of the Genus Eucalyptus, vol. 7, parts 61-70. (N.S.W. Government Printer: Sydney).

Martin, P.G. \& Dowd, J.M. (1993) Partial sequences of ribosomal RNA of Papilionaceae and related families. Phytochemistry 33: 361-363.

Nicolle, D. \& Conran, J.G. (1999) Variation in the Eucalyptus flocktoniae complex (Myrtaceae) and the description of four new taxa from southern Australia. Austral. Syst. Bot. 12: 207-239.

Poisson, J. (1874) Recherches sur les Casuarina et en particulier sur ceux de la Nouvelle-Calédonie. Nouv. Arch. Mus. Hist. Nat. sér. 1, 10: 59-111.

Prider, J. (1998) The population structure and reproductive biology of Gymnostoma australianum L. Johnson. Unpublished B.Sc. (Honours) thesis, University of Adelaide.

Scriven, L.J. \& Christophel, D.C. (1990) A numerical taxonomic study of extant and fossil Gymnostoma. Pp. 137-147, in Douglas, J.G. \& Christophel, D.C. (eds), Proceedings of the 3rd International Organisation of Palaeobotanists Conference. (A-Z Printers: Melbourne).

Scriven, L.J. \& Hill, R.S. (1995) Macrofossil Casuarinaceae: their identification and the oldest macrofossil record, Gymnostoma antiquum sp. nov. from the Late Paleocene of New South Wales. Austral. Syst. Bot. 8: 1035-1053.

Torrey, J.G. (1983) Root development and root nodulation in Casuarina. Pp. 180-192, in Midgley, S.J., Turnbull, J.W. \& Johnston, R.D. (eds), Casuarina Ecology, Management and Utilization. (CSIRO: Melbourne).

Torrey, J.G. \& Berg, R.H. (1988) Some morphological features for generic characterisation among the Casuarinaceae. Amer. J. Bot. 75: 864-874.

Turnbull, J.W. \& Martensz, P.N. (1982) Aspects of seed collection, storage and germination in Casuarinaceae. Austral. Forest Res. 12: 281-294.

Weberling, F. \& Leenhouts, P.W. (1966) Systematisch-morphologische Studien an Terebinthales-Familien (Burseraceae, Simaroubaceae, Meliaceae, Anacardiaceae, Sapindaceae). Akad. Wiss. Abh., Math.-Naturwiss. Kl. 10: 536-542, 570-571.

Williams, R.F. \& Metcalf, R.A. (1985) The genesis of form in Casuarinaceae. Austral. J. Bot. 33: 563-578.

Wilson, K.L. \& Johnson, L.A.S. (1989) Casuarinaceae. Pp. 100-174, in George, A.S. (ed.) Flora of Australia, vol. 3. (AGPS: Canberra).

\section{Manuscript recieved 16 September 1999 Manuscript accepted 22 March 2000}


